\title{
APPLICATION OF MANN-KENDAL (MK) TEST IN TREND ANALYSIS OF AIR TEMPERATURE AND PRECIPITATION: CASE OF MAČVA DISTRICT (SERBIA)
}

\author{
NIKOLA MILENTIJEVIĆ ${ }^{*}$ ， NIKOLA BAČEVIĆ ${ }^{1}$ ， DUŠAN RISTIĆ 1 , ALEKSANDAR \\ VALJAREVIĆ ${ }^{2}$, MILANA PANTELIĆ ${ }^{3}$, DUŠAN KIĆOVIĆ ${ }^{4}$
}

${ }^{1}$ Faculty of Sciences, University in Priština, Kosovska Mitrovica, Serbia

${ }^{2}$ Faculty of Geography, University of Belgrade, Belgrade, Serbia

${ }^{3}$ Faculty of Sciences, University of Novi Sad, Novi Sad, Serbia

${ }^{4}$ The College of Tourism, Academy of Applied Studies, Belgrade, Serbia

\begin{abstract}
Recent climate changes cause significant natural and socio-economic consequences. They represent one of the major environmental problems of the late $20^{\text {th }}$ and early $21^{\text {st }}$ centuries. Changes in temperature and precipitation play a significant role in understanding climate change issues. They include numerous extreme climatic events such as heat waves, droughts, forest fires and more. Looking at regional differences in temperature and precipitation regime change, Southern Europe, including the Republic of Serbia, occupies a special place. The Mačva district $\left(3.272 \mathrm{~km}^{2}\right)$ is almost four times as spacious as the Mačva area. The administrative-political division of the Mačva district is comprised of eight municipalities. The paper presents trends of two climate variables: mean annual air temperature and mean annual precipitation in the study area. In methodological sense, the main statistical procedure is the non-parametric Mann-Kendall (MK) test. Data from three available meteorological stations in the Mačva district (1949-2015) were used for the analysis. The presented results of the trends in air temperature indicate that there is a statistically significant positive trend in all-time series. In trends, precipitation amounts a statistically significant positive trend was observed in two time series, while in one there is no trend. The expressed trends, especially in the case of air temperatures, lead to the possibility of drought. Mačva district and Mačva have some agricultural importance in the Republic of Serbia. For these reasons, some adaptation to climate change is needed as arid conditions lead to fluctuations in agricultural yield.
\end{abstract}

Keywords: Climate change, Air temperature trends, Precipitation trends, Mann Kendall test, Mačva district (Serbia).

\section{INTRODUCTION}

Fifth Assessment Report the Intergovernmental Panel on Climate Change (IPCC, 2014) highlights several important conclusions: a) over the past hundred years, the average temperature on Earth has increased by $0.6{ }^{\circ} \mathrm{C}$. During this interval, two warming periods are distinguished - from 1910 to 1945 and from 1976 to the present; b) "the period from 1983 to 2012 is probably the hottest 30 -year series on the northern hemisphere in the last 1400 years"; c) the past three decades have been the warmest during the instrumental period. Each decade was successively warmer than the previous one, so the first decade of the 21 st century was the warmest since 1850 .

Apart from the report, many authors have addressed the issue of climate change. According to Luterbacher et al. (2004) the second half of the twentieth century and the beginning of the twenty-first century (1974-2003) make up the hottest 30-year series. This is in line with the latest Intergovernmental Panel on Climate Change Report. Blunden et al. (2018) found that since

*Corresponding author: nikola.milentijevic@pr.ac.rs GEOGRAPHY, GEOSCIENCE AND ASTRONOMY instrumental measurements were made (1880-2012), the average global air temperature has shown a growth trend of $0.85^{\circ} \mathrm{C}$.

Regional differences are below or above the established limit (in the range of 0.65 to $1.06{ }^{\circ} \mathrm{C}$ ). The most intense warming in recent decades has been observed in the temperate latitudes of the Northern Hemisphere (Fei et al., 2014). During the twentieth century, air temperatures rose almost throughout the whole Europe. However, regionally, the largest changes in annual and seasonal air temperatures have been identified in Northern Europe latitudes (Kovats et al., 2014). Since 1980, warming has been most intense above Scandinavia (especially in winter), while warming in the Iberian Peninsula is pronounced during the summer months (EEA, 2012). Climate change is particularly affecting the area of Southeast Europe.

There are numerous authors who have analyzed the annual trends in air temperature: in Slovenia (Milošević et al., 2013; Milošević et al., 2017), Montenegro (Burić et al., 2014a), Serbia (Unkašević \& Tošić, 2013; Bajat et al., 2015; Gavrilov et al., 2015; Gavrilov et al., 2016; Gavrilov et al., 2018; Bačević et al., 2018), Greece (Mamara et al., 2016), and Bosnia and Herzegovina (Trbić et al., 2017; Popov et al., 2018a; Popov et al., 2018b). 
Globally, there are trends in increasing precipitation (Nguyen et al., 2018). However, regional variations in precipitation do not follow global trends. From 1900 to 2005, precipitation decreased in the Sahel, the Mediterranean, South Africa and parts of South Asia. These trends have been expressed especially since the 1980s (Spinoni et al., 2017). The exception is North Africa, northern Italy and the western part of the Iberian Peninsula where a trend of increasing precipitation has been observed (Philandras, 2011). The annual rainfall since 1960 shows a trend increase of $70 \mathrm{~mm}$ per decade in Northern Europe and Western Europe. A decrease in the sum of $90 \mathrm{~mm}$ per decade has been reported in Southern Europe (EEA, 2017).

Precipitation variability as an indicator of climate change in Southeast Europe was addressed by: in Serbia (Gocić \& Trajković, 2013; Tošić et al., 2014a; Tošić \& Unkašević, 2014b; Putnikovć \& Tošić, 2018), Montenegro (Burić et al., 2014b; Burić et al., 2018a; Burić et al., 2018b), Slovenia (Tošić et al., 2016), Greece (Markonis et al., 2017); Bosnia and Herzegovina (Popov et al., 2019a; Popov et al., 2019b).

The subject of this paper is an analysis of recent trends in air temperature and precipitation in the Mačva district, from 1949 to 2015.Mačva district belongs to an important agricultural region in Serbia. One of the sectors most affected by climate change is the agricultural sector (by phenomenon as drought). Irrigation is an effective measure in the fight against drought. Using irrigation systems, in wet years, the unequal distribution of precipitation would be corrected, and in the dry conditions, the humidity deficit would be eliminated. Two important factors that make today's agricultural production unsustainable: a) obsolescence, neglect or absence of irrigation systems; b) the absence of a methodology for forecasting natural disasters, prevention and reduction of damage incurred (Armenski et al., 2014). For this reason, the presented results form the basis of further research of interaction between climate changes and agricultural production. The climate of Mačva as part of the District has been analyzed in climatic terms in several textbooks (Rakićević, 1980; Grčić \& Grčić, 2002; Ducić \& Radovanović, 2005). Numerous attempts at climate change in the former Yugoslavia, and within the framework of Mačva, show a strong compliance (Milutinović, 1974; Rakićević, 1980; Ducić\& Radovanović, 2005; Ivanović et al., 2016). According to A. Milutinović (1974) Mačva belongs to the Cfwbx variant of moderately warm and humid climate (according to Kepen's climate classification).

T. Rakićević (1980) classified Mačva in the KolubaraMačva climate region. The mean temperatures of the hottest month in the annual flow of air temperature, July, are between 20-22 ${ }^{\circ} \mathrm{C}$, while the annual precipitation amounts are between 600-800 mm. Ducić \& Radovanović (2005) They classify Mačva in the Climate Area A (Subarea A-1-a). These are conditions of continental climate. However, there is a serious lack of literature in the field of climate research (Ćirković, 1977; Gajić \&
Vujadinović, 2007). The reasons for the inadequate treatment of climate change problems are the small size of the territory and the lack of the relevant meteorological stations. A larger number of stations would result in better spatial distribution of climate parameters, which would allow for more adequate climate analysis.

\section{THEORETICAL PART}

Study area

The plain of Mačva represents a special sub-continent within the Pannonian Basin. Its borders are natural: the Sava River in the north and east, the lower course of the Drina River in the west and the Pocerina River in the south. It is dissected by a dense network of river flows belonging to the Drina, Sava and Kolubara basins. The area of Mačva is $860 \mathrm{~km}^{2}$. In the administrative-political sense, the Mačva district is a far larger entity $\left(3.272 \mathrm{~km}^{2}\right)$. It is composed of the following municipalities: Bogatić, Vladimirci, Koceljeva, Krupanj, Loznica, Ljubovija, Mali Zvornik and Šabac (Grčić\& Grčić, 2002). There is only one meteorological station in the territory of Mačva (MS Šabac). For this reason, the study area was extended to the entire district, where two more meteorological stations (MS Loznica and MS Ljubovija) were located. The area defined in this way (Figure 1), with more stations, makes it possible to represent more time series. In this way, a better analysis of the trends is obtained.

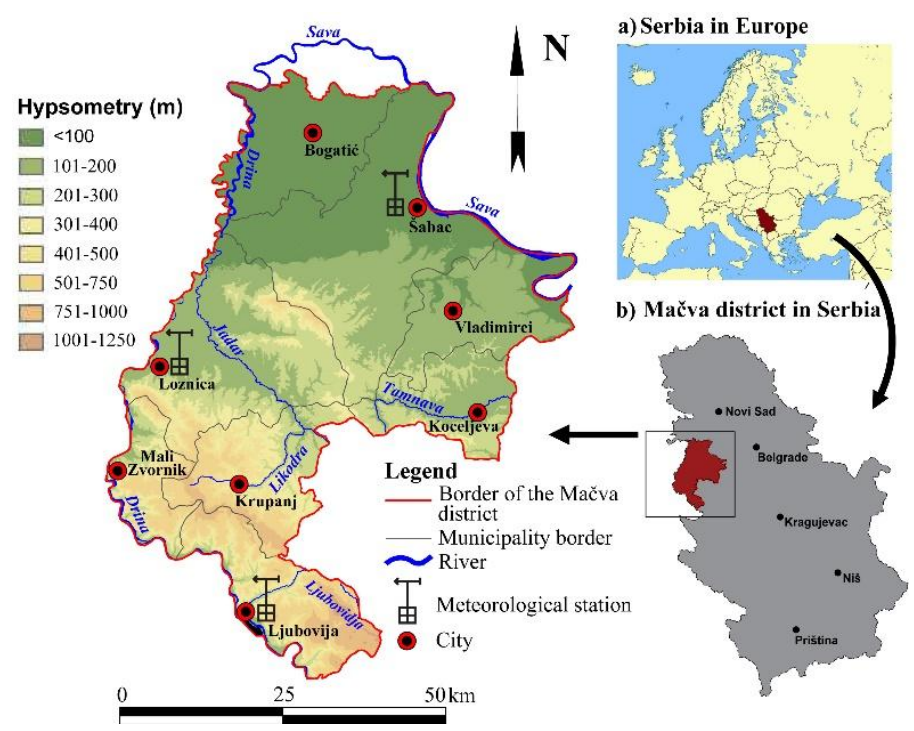

Figure 1. Map location of Mačva district in Republic of Serbia, with selected meteorological stations.

\section{EXPERIMENTAL PART}

\section{Materials and methods}

For the purposes of the paper, an analysis of selected climatic parameters was performed for a 66-year data set. Data from 3 meteorological stations, taken from the Meteorological 
Yearbooks of the Republic Hydrometeorological Service of Serbia (RHSS, 2019) were used. Climate variables are categorized into two groups of data: mean annual air temperature (YT) and mean annual precipitation (YP). The analysis of selected variables by weather stations determined a total of six time series. Each of the six time series is indicated by a corresponding acronym containing the abbreviation for the year and air temperature or precipitation (Table 1).

Table 1. Acronyms for 6 time series per meteorological station based on the abbreviation for the year and selected climate variable.

\begin{tabular}{|c|c|}
\hline Station & Year $(\mathbf{Y})$ \\
\hline \multirow{2}{*}{ Sabac } & $\check{S}-Y T$ \\
\cline { 2 - 2 } & $\check{S}-Y P$ \\
\hline \multirow{2}{*}{ Loznica } & $L-Y T$ \\
\cline { 2 - 2 } & $L-Y P$ \\
\hline \multirow{2}{*}{ Ljubovija } & $L j-Y T$ \\
\cline { 2 - 2 } & $L j-Y P$ \\
\hline
\end{tabular}

Trends in air temperature and precipitation were processed using three statistical approaches: a) the trend equation was determined individually for each time series; b) the trend magnitude $(\Delta y)$ is calculated based on the trend equation; v) apart from these procedures, the existence or absence of a trend was analyzed using a non-parametric Mann-Kendall (MK) test. The essence of the first statistical procedure is to determine the slope size of the selected variable in the trend equation. There are three possible scenarios here: a) the slope size is greater than zero - the trend is positive; b) the slope size is less than zero - the trend is negative; v) slope equals zero - there is no trend. Based on the trend equation, the magnitude (change) of the trend was determined as the difference of parameters (air temperature and/or precipitation) at the beginning and end of the period. The period means the analyzed interval, from 1949 to 2015 . At trend magnitude, there are three possible scenarios: a) when $\Delta y$ is greater than zero - the trend is negative; b) when $\Delta y$ is less than zero - the trend is positive; v) when $\Delta y$ equals zero - there is no trend. (Gavrilov et al., 2015; Gavrilov et al., 2016). The third statistical procedure is the most complex and involves the analysis of time series using the MK test (Kendall, 1975; Gilbert, 1987). This test has wide application in the interpretation of climatological time series, e.g. air temperature and precipitation (Karmeshu, 2012), extreme temperatures (Wibig \& Glowicki, 2002), aridity as an indicator of climate change (Hrnjak et al., 2014; Bačević et al., 2017; Radaković et al., 2017; Milentijević et al. al., 2018). Its advantages are ease of use and manipulation of missing values. According to MK test, two hypotheses were tested: $\mathrm{H}_{0}$ (null hypothesis) where there is no trend in time series; and the alternative hypothesis $\left(\mathrm{H}_{\mathrm{a}}\right)$, where there is a statistically significant trend in time series, for the selected significance level $(\alpha)$. The probability (p) was calculated in order to determine the level of significance in the hypotheses. Microsoft Office Excell 2007 software and its XLSTAT extension (https://www.xlstat.com/en) were used to analyze the data.

Inhomogeneity in time series can cause the incorrect interpretation of climate time series (Rahman et al., 2017), and be misleading in the interpretation of tendencies in the time series. Several methods can be used to detect abrupt changes: Alexandersson's test (Alexandersson, 1986), Pettitt's test (Kocsis et al., 2019).Savić et al. (2012) applied homogeneity test on example of Vojvodina (Serbia) according to Alexandersson (1986). In this paper time time series related to air temperature values were tested. The test of homogeneity points to relatively low differences of mean monthly (from $0^{\circ} \mathrm{C}$ to $0.12^{\circ} \mathrm{C}$ ) and trend (from $0^{\circ} \mathrm{C}$ to $0.001^{\circ} \mathrm{C}$ ) air temperatures values between raw and homogenised time series. Authors Tošić et al. (2014b) analyzed wet and dry periods in Serbia, by application of the same method. Their conclusions are similar to previous research (homogeneity is determined in all time series related to precipitation). In this paper none of presented homogeneity tests wasn't applied. Main reasons can be summarised in the following statements: a) small territory of Mačva district; b) small distance between meteorological stations; c) the dataset was complete, without missing data.

\section{RESULTS AND DISCUSSION}

\section{Trend parameters}

The paper presents the results for 6 time series. For each time series, the trend equation, linear trend, and MK test analysis (from 1949-2015) were determined. The analysis was supplemented with trend magnitude $(\Delta y)$ and trend probability (p) for each time series from the selected meteorological station. The results are summarized in Tables 2 and 3 and Figure 1.

Table 2. Trend equation (y), trend magnitude $(\Delta y)$, and reliability probability (p) for mean annual air temperature (YT).

\begin{tabular}{|c|c|c|c|}
\hline Time series & Trend equation & $\Delta y\left({ }^{\circ} \mathrm{C}\right)$ & $p(\%)$ \\
\hline$S$ S $Y T$ & $y=0.0138 x+10.94$ & 0.9 & $<0.0001$ \\
\hline$L-Y T$ & $y=0.0228 x+10.636$ & 1.5 & $<0.0001$ \\
\hline$L j-Y T$ & $y=0.0202 x+10.074$ & 1.3 & $<0.0001$ \\
\hline
\end{tabular}

Table 3. Trend equation (y), trend magnitude ( $\Delta \mathrm{y})$, and reliability probability (p) for mean annual precipitation (YP).

\begin{tabular}{|c|c|c|c|}
\hline Time series & Trend equation & $\Delta y(\mathrm{~mm})$ & $p(\%)$ \\
\hline$S-Y P$ & $y=0.9538 x+656.24$ & 62.9 & 0.1517 \\
\hline$L-Y P$ & $y=1.3753 x+797.6$ & 90.8 & $<0.0001$ \\
\hline$L j-Y P$ & $y=1.8657 x+838.73$ & 123.1 & $<0.0001$ \\
\hline
\end{tabular}

\section{Trend assessment}

The obtained MK test results for mean annual air temperatures and mean annual rainfall in the Mačva district are shown in Table 4. The analysis of selected time series identifies two key statements: a) in five time series cases there is a statistically significant positive trend; $b$ ) only in the case of the 
time series relating to precipitation $(\breve{S}-Y P)$ there is no established trend. The results obtained in this way are confirmed by the numerical parameters presented (Table 4 and Figure 2).
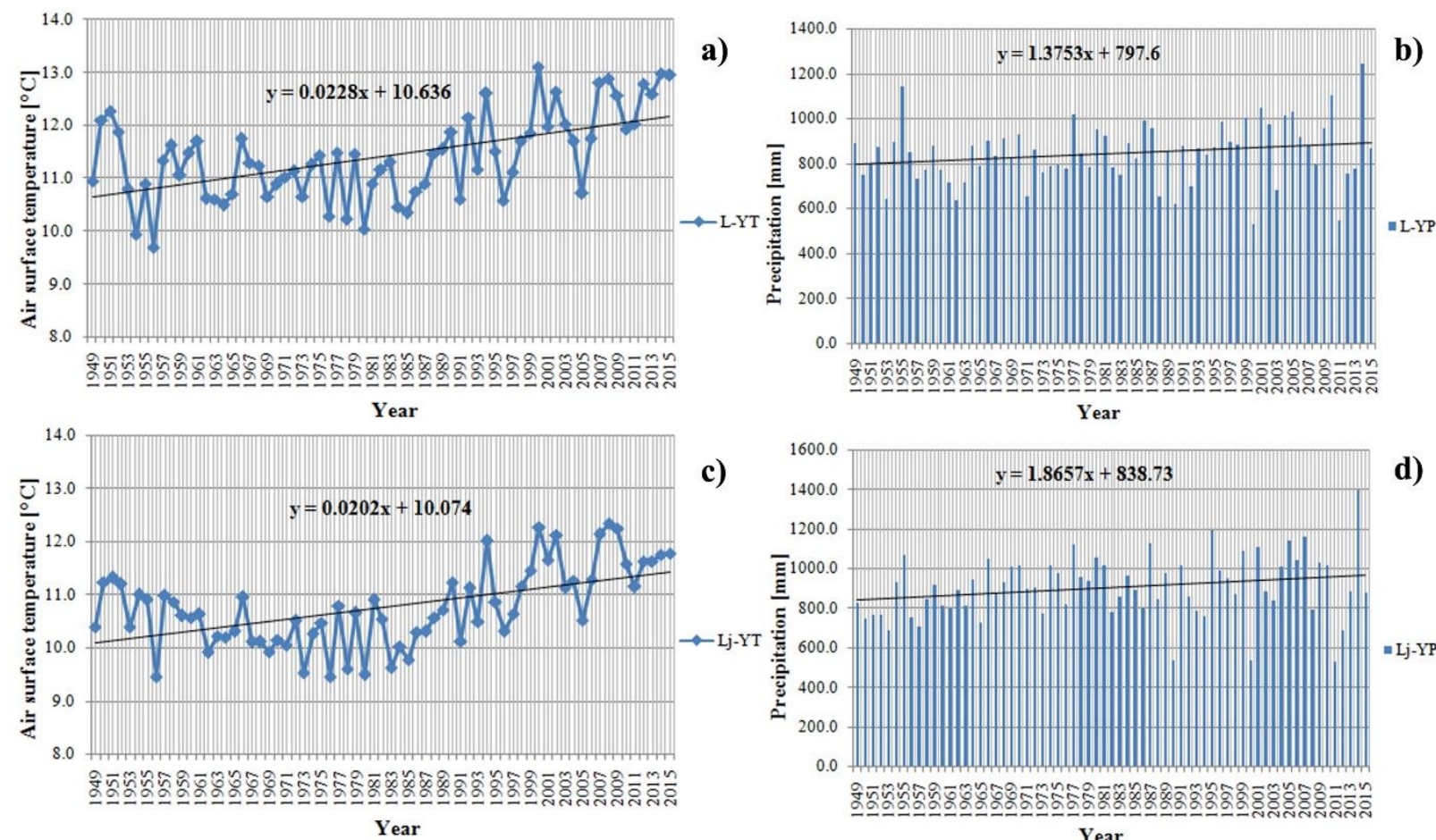

c)
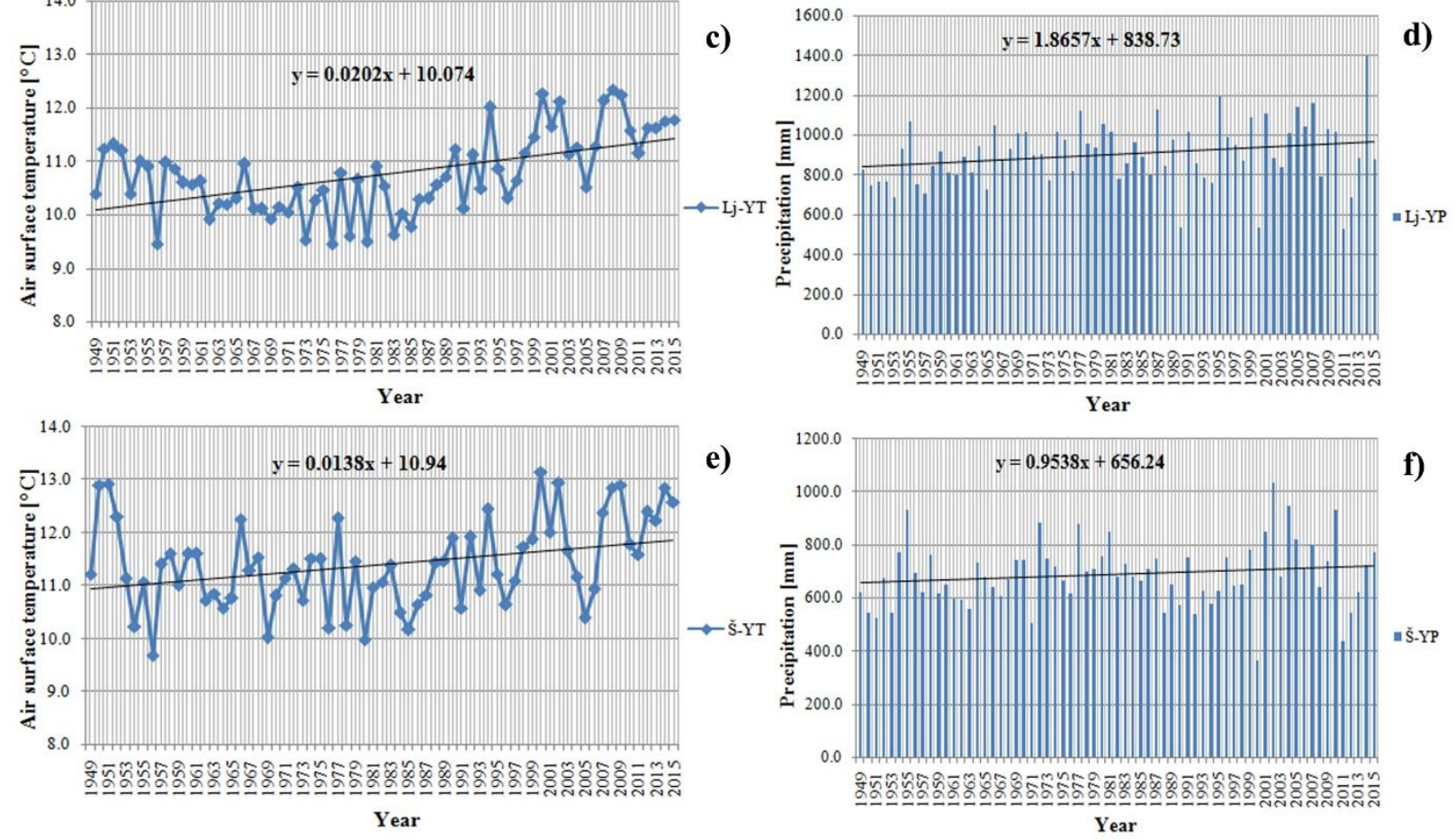

Figure 2. Linear trends: a, b) mean annual air temperatures and precipitation amount measured in Loznica meteorological station; c, d) mean annual air temperatures and precipitation for the Ljubovija meteorological station; e, f) mean annual air temperatures and precipitation for the Šabac meteorological station.

Table 4. Summary results of the trend analysis of annual air temperatures and precipitation in the Mačva district (1949-2015).

\begin{tabular}{|c|c|c|}
\hline Time series & Trend equation & Standard MK test \\
\hline$L-Y T$ & Positive trend & $\begin{array}{c}\text { Statistically significant } \\
\text { positive trend }\end{array}$ \\
\hline$L j-Y T$ & Positive trend & $\begin{array}{c}\text { Statistically significant } \\
\text { positive trend }\end{array}$ \\
\hline$\check{S}-Y T$ & Positive trend & $\begin{array}{c}\text { Statistically significant } \\
\text { positive trend }\end{array}$ \\
\hline$L-Y P$ & Positive trend & $\begin{array}{c}\text { Statistically significant } \\
\text { positive trend }\end{array}$ \\
\hline$L j-Y P$ & Positive trend & $\begin{array}{c}\text { Statistically significant } \\
\text { positive trend }\end{array}$ \\
\hline$S \check{S}-Y P$ & No trend & No trend \\
\hline
\end{tabular}

In the Mačva district, for time series relating to the mean annual air temperature L-YT, Lj-YT and Š-YT, the p value is the same and amounts to $<0.0001$. There is a statistically significant positive trend in these time series. As the computed p-value is lower than the significance level alpha $=0.05$, they should reject the null hypothesis $\mathrm{H} 0$, and accept the alternative hypothesis $\mathrm{Ha}$. The risk to reject the null hypothesis is $\mathrm{Ha}$, while it is true is lower than $0.01 \%$.

Similar results can be identified in the literature. KleinTank \& Können (2003) have established a trend of increasing air temperature in Europe since 1979, both on an annual and seasonal basis. Milosevic et al. (2017) in Slovenia have identified a significant increase in mean annual, mean maximum and mean minimum air temperatures (per decade of $0.3-0.5^{\circ} \mathrm{C}$ ). By analyzing data from 52 meteorological stations in Greece, 
Mamara et al. (2016) found a negative trend between 1960 and 1976. A statistically significant positive trend has been reported since 1977-2004. years. Similarly, in the near region temperature increase is dominant in Montenegro (Burić et al., 2014), Bosnia and Herzegovina (Trbić et al., 2017; Popov et al., 2018a; Popov et al., 2018b). In the territory of Serbia in the region of Vojvodina (Gavrilov et al., 2015; Gavrilov et al., 2016) and in Kosovo and Metohija (Gavrilov et al., 2018) positive trends in air temperature were also observed.

Time series in terms of mean sums of precipitation in the Mačva District show slightly different results. In two time series, L-YP and Lj-YP, a statistically significant positive trend was observed. The only time series from all analyzed in which there is no trend is W-YP. For the above time series, the $\mathrm{p}$ value is $<0.0001$. As the computed $\mathrm{p}$-value is lower than the significance level alpha $=0.05$, one should reject the null hypothesis $\mathrm{H} 0$, and accept the alternative hypothesis Ha. The risk to reject the null hypothesis $\mathrm{Ha}$, while it is true is lower than $0.01 \%$. For time seris Š-YP, $p$ value is 0.1517 . As the computed p-value is greater than the significance level alpha $=0.05$, one cannot reject the null hypothesis H0. The risk to reject the null hypothesis $\mathrm{H} 0$ while it is true is $15.18 \%$.

There is some agreement on increasing precipitation in the study area and globally. The Mediterranean area is exposed to a decrease in average rainfall. This scenario is expected to continue in the future, with the $20 \%$ decrease (IPCC, 2014). An example of a Mediterranean country that showed a similar scenario is Greece (Markonis, 2016). These authors have found a decrease in annual precipitation over most of the territory since 1950. However, since the 1980s, there has been a trend of increasing annual precipitation. For these reasons, it is difficult to find similar results in the literature in terms of increasing rainfall over a wider area. Decrease of rainfall is dominant in Bosnia and Herzegovina (Popov et al., 2019a), Montenegro (Burić et al., 2018a; Burić et al., 2018b), Slovenia (Milošević et al., 2013; Milošević et al., 2013). 2017). The paper by Gocić \& Trajković (2013) found that there is no trend in the case of annual rainfall at most stations in Serbia. A positive trend was observed at the seasonal level, during the autumn and winter months. Analyzing precipitation trends in Vojvodina, Tošić et al. (2014) found that there are positive trends in precipitation on a yearly and seasonal basis (winter and autumn). Rainfall trends were observed during spring and winter.

\section{CONCLUSION}

Based on the results presented, it is difficult to draw general conclusions, but certain conclusions can be drawn. First, positive trends in air temperatures are dominant. These trends can be explained by the effect of global warming, which is also expressed at regional and local level (Hardy, 2006). In the case of precipitation, positive trends dominate in two time series, while one time series does not establish a trend. This is generally in line with global precipitation trends, however, in recent decades the Mediterranean has seen a decrease in precipitation. For these reasons, further research into these cases is needed in order to determine possible causes. Thus, it would be desirable to analyze other parameters (temperature extremes, air temperature and precipitation by season). That is why this paper provides a solid foundation in future climate research as it provides insights into the dynamics of climate over the past decades. Also, future projections of climate in Europe and the Mediterranean predict a higher incidence of extreme climate events, such as drought. Drought is causing a number of socio-economic changes related to nature, agriculture and available water resources. Therefore, it is necessary to implement appropriate adaptation measures (Bressers et al., 2016). Mačva district and Mačva, as a significant agricultural area, require some adaptation measures to climate change, as defined by the Report of the Republic of Serbia under the UN Framework Convention on Climate Change (Ministry of Environmental Protection, 2017).

\section{ACKNOWLEGMENTS}

This paper was created as a result of project No. III43007 funded by the Ministry of Education, Science and Technological Development of the Republic of Serbia.

\section{REFERENCES}

Alexandersson, H. 1986. A homogeneity test applied to precipitation data. Journal of Climatology, 6, pp. 661-675.

Armenski, T., Stankov, U., Dolinaj, D., Mesaroš, M., Jovanović, M., Pantelić, M., Pavić, D.,Popov, S., Popović, Lj., Frank, A., \& Ćosić, Đ. 2014. Social and Economic Impact ofDrought on Stakeholders in Agriculture, Geographica Pannonica, 18(2), pp. 34-42. doi: 10.5937/GeoPan1402034A

Bačević, R. N., Vukoičić, Z. D., Nikolić, M., Janc, N., Milentijević, N., \& Gavrilov, B. M. 2017. Aridity in Kosovo and Metohija, Serbia. Carpathian Journal of Earth and Environmental Sciences, 12(2), pp. 563-570.

Bačević, R. N., Pavlović, M., \& Rašljanin, I. 2018. Trend Assessing Using Mann-Kendall'sTest for Priština Meteorological Station Temperature and Precipitation Data, Kosovo and Metohija, Serbia. The University ThoughtPublication in Natural Sciences, (8)2, pp. 39-43. doi: 10.5937/univtho8-19513

Bajat, B., Blagojević, D., Kilibarda, M., Luković, J., \& Tošić, I. 2015. Spatial Analysis of the Temperature Trends in Serbia during the Period 1961-2010. Theoretical and Applied Climatology, 121(1), pp. 289-301.

Blunden, J., Arndt, D. S., \& Hartfield, G. 2018. State of the Climate in 2017, Bulletin of American Meteorogical Society, 99(8), Si-S332.

Burić, D., Luković, J., Ducić, V., Dragojlović, J., \& Doderović, M. 2014a. Recent trends in daily temperature extremes over southern Montenegro (1951-2010), Natural Hazards Earth Systems. Sci., 14, pp. 67-72.

Burić, D., Ducić, V., Mihajlović, J., Luković, J., \& Dragojlović, J. 2014b. Relationship between the precipitation variability in 
Montenegro and the Mediterranean oscillation. Bulletin of the Serbian Geographical Society. 94(4), pp. 109-120. doi: 10.2298/GSGD1404109B

Burić, B. D., Dragojlović, M. J., Milenković, M., Popović, Z. Lj., \& Doderović, M. M. 2018a. Influence of variability of the East Atlantic Oscillation on the air temperature in Montenegro. Thermal Science. 22(1B), pp. 759-766.

Burić, D., Ducić, V., \& Mihajlović, J. 2018b. Relationship between mean annual temperatures and precipitation sums in Montenegro between 1951-1980 and 1981-2010 periods. Bulletin of the Serbian Geographical Society, 98(1), pp. 3148.

Bressers, J. T. A., Bressers, N., \& Larrue, C., (Ed.) 2016. Governance for Drought Resilience: Land and Water Drought Management in Europe. Springer.

Ćirković, Lj. 1977. Climate properties of Western Serbia. Collection of Papers of Geographical Institute "Jovan Cvijić", 29, pp. 105-133. (In Serbian)

Ducić, D. \& Radovanović, M. 2005. Climate of Serbia. Belgrade: ZUNS. (In Serbian)

European Environment Agency (EEA), 2017. Climate change, impacts and vulnerability in Europe 2016, an indicator based report (EEA Report No. 1/2017). European Environment Agency, Copenhagen.

Fei, J., Zhaohua, W., Jianping, H., \& Chassignet, E. P. 2014. Evolution of Land Surface Air Temperature Trend. Nature Climate Change, 4, pp. 462-466.

Gajić, M., \& Vujadinović, S. 2007. Thermal Regime in the area of Jadar. Collection of Papers, Faculty of Geography, LV, pp. 29-38. (In Serbian).

Gavrilov, M. B., Marković, S. B., Jarad, A., \& Korać, V. M. 2015. The analysis of temperature trends in Vojvodina (Serbia) from 1949 to 2006. Thermal Science. 19(2), pp. 339350.

Gavrilov, M. B., Tošić, I., Marković, S. B., Unkašević, M., \& Petrović, P. 2016. The analysis of annual and seasonal temperature trends using the Mann-Kendall test in Vojvodina, Serbia. Időjárás. 122(2), pp. 203-216.

Gavrilov, M. B., Marković, S. B., Janc, N., Nikolić, M., Valjarević, A., Komac, B., Zorn, M., Punišić, M., \& Bačević, N. 2018. Assessing average annual air temperature trends using the Mann-Kendall test in Kosovo. Acta geographica Slovenica. 58(1),pp. 8-25.

Gilbert, R. O. 1987.Statistical methods for environmental pollution monitoring. New York: Van Nostrand Reinhold.

Gocic, M., \& Trajkovic, T. 2013. Analysis of precipitation and drought data in Serbia over the period 1980-2010,Journal of Hydrology, 494, pp. 32-42.

Grčić, M. \& Grčić, Lj. 2002. Mačva, Posavina and Pocerina, Belgrade: Faculty of Geography. (In Serbian)

Hardy, J., T. 2006. Climate change - causes, effects and solutions. Chichester.

Hrnjak, I., Lukić, T., Gavrilov, M. B., Marković, S.B.,Unkašević, M., \& Tošić, I.2014. Aridity in Vojvodina, Serbia. Theoretical and Applied Climatology, 115(1-2), pp. 323-332.

IPCC, 2014. Climate change 2014: synthesis report, in: Core Writing Team, Pachauri, R. K., Meyer, L. A., (Eds.), Contribution of Working Groups I, II and III to the Fifth
Assessment Report of the Intergovernmental Panel on Climate Change. IPCC, Geneva, pp. 151.

IPCC, 2018. Summary for Policymakers. In: Masson-Delmotte V, Zhai P, Pörtner HO, Roberts D, Skea J, Shukla PR, Pirani A, Moufouma-Okia W, Péan C, Pidcock R, Connors S, Matthews JBR, Chen Y, Zhou X, Gomis MI, Lonnoy E, Maycock T, Tignor M, Waterfield T (eds.) Global warming of $1.5^{\circ} \mathrm{C}$. An IPCC Special Report on the impacts of global warming of $1.5^{\circ} \mathrm{C}$ above pre-industrial levels and related global greenhouse gas emission pathways, in the context of strengthening the global response to the threat of climate change, sustainable development, and efforts to eradicatepoverty. World Meteorological Organization, Geneva, pp. 3-24.

Ivanović, R., Valjarević, A., Vukoičić, D., \& Radovanović, D. 2016. Climatic regions of Kosovo and Metohija. The University Thought-Publication in Natural Sciences, 6(1), pp. 49-54. doi: 10.5937/univtho6-10409

Karmeshu, N. 2012. Trend detection in annual temperature \& precipitation using the Mann Kendall Test - a case study to assess climate change on select states in the northeastern United States. Master's thesis, University of Pennsylvania. Philadelphia.

Kendall, M.G. 1975. Rank correlation methods

Klein Tank, A. M. G. \& Können, G. P., 2003. Trends in Indices of Daily Temperature and Precipitation Extremes in Europe, 1946-99. Journal of Climate, 16(22), pp. 3665-3680.

Kocsis, T., Kovács-Székely, I., \& Anda, A. 2019. Homogeneity tests and non-parametric analyses of tendencies in precipitation time series in Keszthely, Western Hungary. Theoretical and Applied Climatology.doi:10.1007/s00704019-03014-4

Kovats, R. S., Valentini, R., Bouwer, L. M., Georgopoulou, E., Jacob, D., Martin, E., Rounsevell, M., \& Soussana, J. F. 2014. Europe. In: Climate Change 2014: Impacts, Adaptation, and Vulnerability. Part B: Regional Aspects. Contribution of Working Group II to the Fifth Assessment Report of the Intergovernmental Panel on Climate Change [Barros, V.R., C.B. Field, D.J. Dokken, M.D. Mastrandrea, K.J. Mach, T.E. Bilir, M. Chatterjee, K.L. Ebi, Y.O. Estrada, R.C. Genova, B. Girma, E.S. Kissel, A.N. Levy, S. MacCracken, P.R. Mastrandrea, and L.L.White (eds.)]. Cambridge University Press, Cambridge, United Kingdom and New York, NY, USA, pp. 1267-1326.

Luterbacher, J., Dietrich, D., Xoplaki, E., Grosjean, M., \& Wanner, H. 2004. European Seasonal and Annual Temperature Variability, Trends, and Extremes since 1500. Science, 303, pp. 1499-1503.

Mamara, A., Argiriou, A. A., \& Anadranistakis, M. 2016. Recent Trend Analysis of Mean Air Temperature in Greece Based on Homogenized Data. Theoretical and Applied Climatology, 126(3-4), pp. 543-573.

Markonis, Y., Batelis, S. C., Dimakos, Y., Moschou, E., \& Koutsoyiannis, D. 2017. Temporal and spatial variability of rainfall over Greece. Theoretical and Applied Climatology, 130, pp. 217-232.

Milentijević, N., Dragojlović, J., Ristić, D., Cimbaljević, M., Demirović, D. \& Valjarević, A. 2018. The assessment of aridity in Leskovac Basin, Serbia (1981-2010), Journal of the Geographical Institute "Jovan Cvijić", 68(2), pp. 249-264. 
Milutinović, A. 1974. Classification of climate of Yugoslavia according to Köppen and modification of this classification according to our climate properties, SHSS, IX Consulting of climatologist of Yugoslavia, Belgrade. (In Serbian)

Milošević, D., Savić, S. \& Žiberna, I. 2013. Analysis of the Climate Change in Slovenia: Fluctuations of Meteorological Parameters for the Period 1961-2011 (Part I). Bulletin of the Serbian Geographical Society, 93(1), pp. 1-14. doi: 10.2298/GSGD1301001M

Milošević, D., Savić, S., Stankov, U., Žiberna, I., Pantelić, M., Dolinaj, D., \& Leščešen, I. 2017. Maximum temperatures over Slovenia and their relationship with atmospheric circulation patterns. Geografie. 122(1), pp. 1-20.

Ministry of Environmental Protection, 2017. Second National Communication of the Republic of Serbia under the United Nations Framework Convention on Climate Change. Ministry of Environmental Protection, Belgrade.

Nguyen, P. A., Thorstensen, S., Sorooshian, K., Hsu, A., Aghakouchak, H., Ashouri, H. T., \& Braithwaite, D. 2018. Global precipitation trends across spatial scales using satellite observations.Bulletin of the American Meteorological Society. 99, pp. 689-697.

Philandras, C. M., Nastos, P. T., Kapsomenakis, J., Douvis, K. C., Tselioudis, G., \& Zerefos, C. S. 2011. Long term precipitation trends and variability within the Mediterranean region. Natural Hazards and Earth System Sciences. 11, pp. 3235-3250.

Popov, T., Gnjato, S., \& Trbić, G. 2018a. Changes in temperature extremes in Bosnia and Herzegovina: A fixed tresholds-based index analysis. Journal of the Geographical Institute "Jovan Cvijić" SASA. 68(1), pp. 17-33.

Popov, T., Gnjato, S., Trbić, G., \& Ivanišević, M. 2018b. Recent trends in extreme temperature indices in Bosnia and Herzegovina. Carpathian Journal of Earth and Environmental Sciences. 13, pp. 211-224.

Popov, T., Gnjato, S., \& Trbić, G. 2019a. Changes in precipitation over the East Herzegovina region. Bulletin of the Serbian Geographical Society. 99(1), pp. 29-44.

Popov, T., Gnjato, S., \& Trbić, G. 2019b. Analysis of extreme precipitation over the Peripannonian region of Bosnia and Hercegovina. Időjárás. 122(4), pp. 433-452. doi:10.28974/idojaras.2018.4.5

Putniković, S., \& Tošić, I. 2018. Relationship between atmospheric circulation weather types and seasonal precipitation in Serbia. Meteorology and Atmospheric Physics, 130(4), pp. 393-403. doi: 10.1007/s00703-017-0524$\mathrm{y}$
Radaković, G. M., Tošić, A. I., Bačević, R. N., Mađan, D., Marković, S. B. \& Gavrilov, M. B. 2017. The analysis of aridity in Central Serbia from 1949-2015. Theoretical and Applied Climatology, 133(3-4), pp. 887-898. doi:10.1007/s00704-017-2220-8

Rahman, M.A., Yunsheng, L., \&Sultana, N. 2017. Analysis and prediction of rainfall trends over Bangladesh using MannKendall, Spearman's rho tests and ARIMA model. Meteorology and Atmospheric Physics. 129(4), pp. 409-424.

Rakićević, T. 1980. Climate zoning of SR of Serbia. Collection of Papers of Geographical Instite "Jovan Cvijić", 27, pp. 2942.

RHSS, 2019. Official Website RHSS, http://www.hidmet.gov.rs/ciril/meteorologija/klimatologija_g odisnjaci.php (retrieved 10 November 2019)

Savić, S., Milošević, D., Marković, V., \& Kujundžić-Dačović, R. 2012. Homogenisation of Mean AirTemperature Time Series from Vojvodina (North Serbia). Geographica Pannonica. 16(2), pp. 38-43.

Spinoni, J., Naumann, G., \& Vogt, V. J. 2017. Pan-European seasonal trends and recent changes of drought frequency and severity. Global and Planetary Change. 148, pp. 113-130.

Tošić, I., Hrnjak, I., Gavrilov, M. B., Unkašević, M., Marković, S. B., \& Lukić, T. 2014a. Annual and seasonal variability of precipitation in Vojvodina. Theoretical and Applied Climatology, 117,pp. 331-341. doi:10.1007/s00704-0131007-9

Tošić, I., \& Unkašević, M. 2014b. Analysis of wet and dry periods in Serbia. International Journal of Climatology. 34(5), pp. 1357-1368.

Tošić, I., Zorn, M., Ortar, J., Unkašević, M., Gavrilov, M. B., \& Marković, S. B. 2016. Annual and seasonal variability of precipitation and temperatures in Slovenia from 1961 to 2011. Atmospheric Research. 168, pp. 220-233.

Trbić, G., Popov, T. \& Gnjato, S. 2017. Analysis of Air Temperature Trends in Bosnia and Herzegovina. Geographica Pannonica, 21(2), pp. 68-84.

Unkašević, M., \& Tošić, I. 2013. Trends in temperature indices over Serbia: relationships to large-scale circulation patterns. International Journal of Climatology, 33(15), pp. 3152-3161.

Wibig, J., \& Glowicki, B. 2002. Trends of minimum and maximum temperature in Poland. Climate Research, 20, pp. 123-133.

XLSTAT,http://www.xlstat.com/en/ (retrieved 10 December 2019) 